verbalizing suffix, nativizing suffix, adaptational suffix) in order to highlight the functional differences across the various suffixes indicating parts of speech. In classifying suffixes of diverse functions, the author takes stem types into consideration (whether the suffixes concerned are attached to free or to bound stems) on the one hand, and the origin of the stems (whether they are native or borrowed) on the other.

Another aim of the paper is to study the integration of borrowed verbs into the grammatical (phonological, morphological, and syntactic) system of Hungarian. Pre-conquest and postconquest verbal borrowings are strikingly different in whether they involve a derivational suffix of nativization or not, and also in the types of derivational suffixes indicating verbality that participate in the obligatory derivational integration of borrowed verbs.

Keywords: functions of derivational suffixes, derivational suffix indicating part of speech, derivational suffix of integration, derivational suffix of nativization, obligatory derivational integration.

\title{
Az ellentétes mellérendelésről 16-17. századi bibliafordítások nyomán: variáció és változás
}

\section{Bevezetés}

Az alábbi tanulmány az ellentétes mellérendelő mondatszerkezetek funkcionális variációjának néhány aspektusát mutatja be 16-17. századi bibliafordítások összevető elemzésével. Az egyes szöveghelyeket a következő fordítások alapján vetettem össze: Jordánszky-kódex (1519 k.), a vizsolyi biblia (1590) és Káldi György (1626) fordítása, valamint az újszövetségi részeknél tekintetbe vettem Sylvester János fordítását (1541).

A korszakra jellemző mondattörténeti változások a mellérendelés esetében elsősorban a kapcsolóelemek rendszerének gazdagodásával, elsődlegesen a kötőszókészlet bővülésével kapcsolatosak, magának a struktúrának az alakulását azonban ez nem befolyásolja (vö. Haader 2018: 218-20). A pragmatikai szempontok miatt a funkcionális variáció (szinonímia) vizsgálata ilyen esetekben is indokolt, mivel a mondattan terén számos választási lehetőség áll a megnyilatkozó rendelkezésére (Dömötör 2003: 450-1; Haader 2001: 367, 2004: 465-6). Ezáltal az egyéni nyelvhasználatok eltérhetnek a korszakra jellemzőnek tartott állapottól - az egyes szerzők (esetünkben fordítók) nyelvi választásait társadalmi, kulturális beágyazottságuk befolyásolja (vö. Haader 2003: 687).

A bibliafordítások ideálisak a funkcionális szinonímia vizsgálatához, mivel a referenciális tartalom eredendően többé-kevésbé azonos, ugyanakkor a megformálásban többféle szerkezeti lehetőség kínálkozik (Haader 2001: 366-7, 2004: 464-5). A biblikus szövegekre ráadásul az arányokat tekintve átlagon felüli számú mellérendelö kötőszós szerkezet használata jellemző - ez fordítási sajátosságnak (latinnal közvetített hebraizmusnak) tekinthető, ugyanakkor nem kizárt, hogy stíluseszköz a magyarban: erőteljes tagoló hatásával ünnepélyességet kifejezve (akár a szóbeli elbeszélő próza

\footnotetext{
* A tanulmány az MTA Nyelvtudományi Intézetben zajló 116217 számú OTKA-projektum (Versengő szerkezetek a középmagyar élőnyelvben: változók elemzésén alapuló megközelítés) támogatásával készült.
} 
hagyományaiból merítve; Juhász 1991: 500). Éppen ezért az elemzés egyes pontokon kitekint a korszak magánéleti regiszterére is (a Történeti magánéleti korpusz, a továbbiakban TMK alapján; az adatbázis leírását lásd Dömötör et al. 2017).

A magyarban az ellentét altípusainak elhatárolása összefügg a kötőszók viszonylag korán kialakult funkciómegoszlásával. A különböző bibliafordítások összevetése ugyanakkor rámutat a viszonyok jelöltségének, megkülönböztetésének, explicit voltának a kérdéskörére, illetöleg felveti annak kérdését, hogy a hanem terjedését a korszakban milyen szerkezeti tényezők befolyásolhatták (föként a JordK. szövegrészeiben, tekintettel arra, hogy - amint az összehasonlításból kiderült - Sylvester fordítása már nagyrészt az innovatív változatot preferálja, illetőleg más elemet is érint a variáció, például a sőt-öt).

A jelöltséget tekintve a variáció részének kell tekinteni azt, hogy az ellentét különböző fajtái nemritkán kapcsolatos kötőszóval is kifejeződnek. Az egyes források különbséget mutatnak abban a tekintetben, hogy a kapcsolatos kötöszó mely funkciókban és milyen arányban variálódik az ellentétet explicit módon kifejező elemekkel - ez pedig különböző diskurzuspragmatikai motivációkkal magyarázható.

\section{Variáció: tér, idő és humán dimenzió}

A pragmatikai, gyakran korízlési különbségekben gyökerező változatosság és választás feltárásához egyaránt tekintettel kell lenni a tér, az idő és a humán (társadalmi, kulturális) háttérben, dimenzióban rejlö lehetséges magyarázatokra (a dimenzionális megközelítésről bővebben lásd Juhász 2002; variacionista megközelítésben hasonlóképpen, utóbb vö. Tagliamonte 2018). A vizsolyi bibliát Károlyi Gáspár és munkatársai elsősorban latinból fordították, emellett a korábbi magyar kéziratos fordítások is hathattak rá (a héber és a görög forrásokat ellenörzésképpen forgatták; vö. Szabó 2012: 109, a vélhető alapszövegek felsorolása: 110-3). Ha a fordítás céljait és szempontjait figyeljük, akkor jellemzővé válik a szöveghez tapadó módszer, legalábbis a sok hébergörög-latin szókép és a kötött kifejezések visszaadását tekintve. A kötőszóhasználatban ugyanakkor mutatkoznak attitüdök, a normatörekvés jelei, leginkább Sylvester munkáiban, föként a kedig és kediglen kapcsán, valamint az s kötőszó visszaszorításában (Juhász 1999: 453-5; Juhász 2018).

A funkcionális szinonímia feltárása összevető módszerrel történik, megkülönböztetve a szinonim szerkezeteket a formai változatoktól - a funkciójában teljesen azonos vagy annak tekinthető megoldásokat ideértve (Dömötör 2003: 450-1). A forrásban ilyennek mutatkozik a pedig( len) $\sim \operatorname{kedig(~len),~noha~a~} k \sim p$ változatok megítélése (hogy pusztán formai-e) már kérdéses lehet, tekintve, hogy Sylvester elítélő attitüddel viseltetett a pedig iránt (Juhász 1999: 454-5). Ahogy arról szó volt, alapvetően azt tekintjük szinonímiának, ha a szövegek referenciálisan többé-kevésbé ugyanazt valósítják meg (ezt a fordítás ténye lényegében biztosítja), a prezentáció, a megformálás azonban eltérö (Dömötör 2003: 452-3; Haader 2001: 367; Haader 2004: 465-6). A szinonímia kérdése azonban ebben a vizsgált témában összetett és tág értelmezést kíván, hiszen egyaránt ideértendő a lexikális különbség (de mindazonáltal 
pedig), ahogy a szerkezeti különbség is, például az, hogy tagmondatban vagy mondatrészben, például ragvonzó névutós szerkezetben fejeződik-e ki a kérdéses viszony (lásd 5.). További szerkezeti szempont, hogy a kapcsolóelem (de, maga $\sim \operatorname{demaga,}$ hanem) mondatrészeket, tagmondatot vagy annál is nagyobb egységeket, szövegmondatot, akár - biblikus szövegek esetében - verseket kötnek-e össze. Az a kérdéskör is a szinonímia része, hogy az adott szövegrészletben az ellentét viszonya direkt vagy indirekt módon jelölt, azaz a kapcsolóelem explicit-e, vagy implicit, illetőleg kapcsolatos jelentésü vagy ellentétes.

Az ellentét kifejezésének alakulásáról a kései ómagyar korszakot és előzményeit áttekintve a következőket mondhatjuk. A három fö funkció korán kimutatható a kapcsolóelemek által is: a kedig szembeállító és megszorító használatú, ahogy a de is, ez utóbbi azonban tagmondat élén kizáró is lehet, emellett megfigyelhető benne egyfajta „megengedő árnyalat” (Juhász 1991: 486-7, 1992: 781; Papp 1995: 728-9). A hanem ugyancsak nem új keletü, már a KTSz-ban is megszilárdult formában szerepel, ekkor még kiemelő funkcióban. A 16. század elejére az elsődleges kiemelő, megkülönböztető funkció ('hanem csak') átértékelődik, és a hanem a kizáró ellentét kifejezésére ('csak, kizárólag') lesz használatos. A kizáró funkció kifejezésekor kezdetben jellemző volt a tagadó/tiltószó mellett az egyéb, más, senki stb. típusú nyomatékosító elem. A hanem újabb használatának térnyerésével a de a megszorító ellentét kötőszava marad - a változás ingatag voltát mutatja, hogy később, az újmagyar korszakban ismét megjelenik a de ebben a funkcióban (Haader 2003: 774; Haader 2018: 224-5). A szinkrón funkcionálisabb megközelítés több fokozattal, átmenettel számol. Hadrovics László az egyszerü ellentét elnevezésű kategóriába sorolja a szembeállítót és a kizárót is; a megszorító utótagú használat külön csoportot képez (megengedö ellentét), ennek egy árnyalata adja a harmadik csoportot, ez a korlátozó ellentét (ez enyhébb, mint a megengedő, jellemző kötőszava a csak; Hadrovics 1969: 179-80).

A fordítások összehasonlítása a tekintetben is tanulságos lehet, hogy milyen motiváció, szemlélet kerekedik felül gyakrabban: az eredeti szöveghez való ragaszkodás vagy inkább az értés és megértetni akarás (az ómagyar biblikus szövegek kapcsán Juhász 1992: 802). Általánosabb megközelítésben ez megfeleltethető a kontextuális ,,helyénvalóság” és a kontextus felülírása dinamikájának (vö. Roberts 2004: 211-3).

\section{A feltárás néhány előzetes eredményéről}

3.1. A dolgozat az alábbi feltáró bemutatással adalékokat kíván szolgáltatni a korszak egy jellegzetes regiszterével kapcsolatban, csatlakozva a következőkhöz: „A nyelvhasználati kérdéseknek pontosabb feltárása és az abból adódó grammatikai és szociolingvisztikai következtetések levonása a középmagyar korra nézve még későbbi feladat marad" (Haader 2003: 687). Ahogy arról volt szó, a mellérendelő viszonyok módosulása helyett inkább a kifejezőeszközök közötti válogatás (mintázat) a jellemző, a használat gyakorisága gyakran korízlésbeli különbséggel magyarázható (Haader 2003: 686-7, 2018: 224-5). 
Az elemzéshez egészében feldolgoztam az alábbi fejezeteket: Márk evangéliuma, János evangéliuma, Jelenések könyve, Bírák könyve, Józsué könyve. Az újszövetségi részekben négy fordítást vizsgáltam: JordK. (1519 k.), Sylvester (1541), vizsolyi (1590), Káldi (1626); az ószövetségiben pedig hármat: JordK., vizsolyi, Káldi. Emellett részleteket dolgoztam fel Máté és Lukács evangéliumából (Mt 1-11. fejezet; Lk 1-8. fejezet), valamint Mózes negyedik (1-21. fejezet) és Mózes ötödik könyvéböl (1-24. fejezet). Ez utóbbi szövegrészeket szintén a JordK., a vizsolyi biblia és Káldi fordítása alapján vetettem össze.

A többfázisú keresés része, hogy tekintettel kellett lenni az egyik forrásban implicit (zéró), a másik forrásban explicit megoldásokra, az ellentétes jelentésü kapcsolatos kötőszóhasználatra, illetőleg a mellérendeléstől eltérő variációra. Mindezek lépésnek tekinthetők az úgynevezett felelős adatgyüjtés felé. A nyelvi változó meghatározásakor ugyanis elvárható, hogy a célváltozó minden egyes előfordulását számításba vegyük az aktuálisan vizsgált anyagban, és egyúttal az összes nem elöfordulást is számon kell tartani, így az adott jelenség összes változatát feltárjuk a forráscsoportban, beleértve a grammatikailag nem jelölt, implicit megoldásokat is. A szintaktikai, diskurzusbeli/pragmatikai változók esetében azonban a nem előfordulási helyek (ahol megjelenhetne a változat, de ténylegesen mégsem fordul elö) igencsak nehezen írhatók le. A szerkezeti kontextusok szükítése mellett az segíti az ilyen adatkezelést, ha az adott változó csak bizonyos lexémákhoz kapcsolódik, vagy csupán néhány szófaji kategóriát érint (Tagliamonte 2018). - Le kellett azonban végül mondani az olyan ellentétet kifejező szerkezetekröl, amelyekben a kapcsolóelem (föként a pedig) inkább szövegtovábbvivő szerepü (vö. Juhász 1992: 483; Papp 1995: 727). Ennek a funkciónak a bevonása ugyanis parttalanná tette volna a gyüjtést, miközben az ellentét azonosítása ilyenkor problematikus - ehhez ugyanakkor támpontot adnak a párhuzamos szövegrészek (elsősorban a de-vel történő váltakozás).

A kigyüjtött szöveghelyeket az alábbi táblázat foglalja össze, ez az Újszövetség esetében (a négy párhuzamos forrásban összesen) mintegy 2096 adatot jelent, míg az Ószövetség esetében (a három forrásban) 830 adatot - ugyanis mintegy 88 helyen szöveghiány mutatkozott a JordK. anyagában, vélhetően az eltérő eredeti forrásszövegek miatt.

1. táblázat. Az egyes fejezetekből gyüjtött ellentétet kifejező szöveghelyek megoszlása

\begin{tabular}{|c|c|c|c|}
\hline & Szöveghely & & Szöveghely \\
\hline Jelenések & 69 & & 57 \\
\hline Márk & 110 & Józsué & 69 \\
\hline János & 223 & Bírák & 56 \\
\hline Máté 1-11 & 68 & Mózes 4 1-21 & 124 \\
\hline Lukács 1-8 & 54 & Mózes 5 1-24 & 306 \\
\hline ÚSZ összesen: & 524 & ÓSZ összesen: & \\
\hline
\end{tabular}

A szöveghely fogalmának bevezetése szükséges a vizsgált anyagban (jóllehet a megnevezés tág és szubjektív jellegü), ugyanis az ellentétes viszony időnként két vagy akár több bibliai verset kapcsol össze, más esetekben viszont egy versen belül is megfigyelhető többféle ellentét - különböző kifejezőeszközökkel és különböző 
funkciók egyaránt. A szövegpárhuzamoknál az azonos bibliai helyet mindig az első példánál tüntettem fel: ${ }^{1}$

1519 k.: es vralkodnak hw" raytok, hatalmafkodnak hw" raytok; de nem azonkeppen vagyon ty keztetók; de vala ky nagyob akarand lenny, lezen ty zolgalotok (JordK., Mk 10, 42-43).

1590: wralkodnac azokon, és ,a' kic ò kôztôc hatalmasoc, szabadságoc vagyon azokon. [ll] De nem v'gy lészen ti kỏztetec, hanem a' ki akar ti kỏztetec nagy lenni, ti szolgátoc légyen (vizsolyi).

1626: uralkodnak azokon: és az o fejedelmeknek hatalmok vagyon rajtok. Nem úgy vagyon pedig tí-kỏztetek hanem valaki nagyobb akar lenni, inastok lészen (Káldi).

A fenti két szöveghely a versek szerinti beosztástól részben függetlenül két különböző variációs kategóriába sorolható: az első szöveghely funkciók szerint megszorító vs. szembeállító ellentét (a zérót is ideértve), míg a folytatás a kizáró ellentét kifejezőeszközök szerinti variációjába illeszkedik, archaikus de vs. hanem).

A vizsgált anyagban a szinonímia számos ponton megnyilvánul: a két fö tényező a kifejezőeszközök és a funkciók szerinti megoszlás, ezek azonban nem válnak el élesen. Elkülöníthető a teljes megfelelés, ha minden vizsgált szövegváltozatban azonosan fejeződik ki a viszony, ezeket azonban tágabban értelmeztem, beleértve a lexikális szinonímia bizonyos eseteit, például: de $\sim$ demaga $\sim$ mindazonáltal. Ezt a döntést az indokolja, hogy e kapcsolóelemek között jelentősebb különbség nem mutatkozott, és az arányokat sem befolyásolták különösebben. Kvalitatív szempontból ezek némelyike mégis figyelemreméltó, elsősorban a kapcsolóelemek halmozásával kifejezett nyomatékosság miatt, ez leginkább Sylvesterre jellemző (a JordK. az utóbbi esetben is implicit a későbbi forrásokhoz képest):

1519k.: nem dolgolodnak, sem fonnak, sem zw̋nek Mondom byzonnyal tynektek (JordK., Mt 6, 28-29).

1541: nem munkālodnak, sem fonnak, de maga mind az altal ęs mondom tünektek (Sylvester).

1590: nem munkálkodnac és nem fonnac. Mind az által mondom néktec (vizsolyi).

1626: nem munkálkodnak, se nem fonnak. Mondom pedig néktek (Káldi).

\subsection{Variáció, diskurzusbeli funkciók}

A kifejezőeszközöket tekintve teljes megfelelést két csoportra bontottam aszerint, hogy az adott szöveghelyen minden vizsgált fordításban kapcsolatos kötőszó jelöli-e

1 Az alapvetően betűhű szövegközlést technikai okokból egyszerüsítettem, az $s, z$ és $s z$ formákat a mainak megfelelöre cserélve. Az ÚSZ párhuzamos helyei elektronikusan is hozzáférhetök: http://parallelbible.nytud.hu/. 
az ellentétes viszonyt, vagy éppen egyöntetüen ellentétes kötőszó jelenik-e meg az adott helyen. További nagyobb csoportot képez az - ezen a ponton még együtt tárgyalt - bárminemü variáció, amikor is az egyes források közül legalább egy eltérést mutat a többitől. A szöveghelyek megoszlását szemléltető táblázat mutatja, hogy ez utóbbi a legnagyobb arányú mind az ószövetségi, mind az újszövetségi fejezetek összevetésekor, noha az újszövetségi anyag jelentősebb arányú megfelelést mutat az ellentétes kapcsolóelemek terén:

2. táblázat. Variációk és megfelelések a korpuszban

\begin{tabular}{|c|c|c|c|}
\hline Szöveghely & $\begin{array}{c}\text { és-sel kifejezett } \\
\text { ellentét (teljes } \\
\text { megfelelés) }\end{array}$ & $\begin{array}{c}\text { Ellentétes } \\
\text { kapcsolóelem } \\
\text { (teljes megfelelés) }\end{array}$ & $\begin{array}{c}\text { Kifejezőeszközök, } \\
\text { funkciók variációja }\end{array}$ \\
\hline ÓSZ $=306$ & 12 & 33 & 261 \\
\hline ÚSZ $=524$ & 39 & 122 & 363 \\
\hline Összes $=830$ & $51(6 \%)$ & $155(19 \%)$ & $625(75 \%)$ \\
\hline
\end{tabular}

Az ószövetségi fejezetek esetében szót kell ejteni további 23 olyan szöveghelyről, ahol a vizsolyi biblia és Káldi fordítása egyaránt a kizáró hanem-et alkalmazza, a JordK.-beli szöveghiány miatt azonban itt nem vonhatunk egyértelmü párhuzamot (ezért nem került a táblázatba). A diskurzusfunkciót és a jelentést tekintve a nyelvi anyag az alábbi kategóriák szerint csoportosítható: kapcsolatos kötőszóval kifejezett vs. explicit ellentét (és vs. de, ritkábban pedig, hanem); szembeállító vs. egyéb típusú ellentét; megszorító ellentét vs. megengedő alárendelés. A kifejezőeszközöket tekintve külön csoportba kerül a zéró vs. explicit kötőszóval jelölt viszony, valamint a mondatrész vs. tagmondat kifejezte viszony.

A diskurzusfunkciókkal kapcsolatban szót kell ejteni az egyes szövegpárhuzamokból adódó további változatosságról: az ellentét egyes fajtái (főként a kizárás) az oksági viszonyokkal mutatnak párhuzamot:

1590: Zebulun sem ůzé ki a Chanaanęust, ki Gazerben lakic vala, annac okáért lakéc az Chananęus o̊ko̊zôtto̊c Gazerbe (vizsolyi, Bír 1, 30).

1626: Zábulon el nem tơrlé a’ Czetron és Náalól lakóit: hanem kỏzo̊ttek lakék a’ Kananæus (Káldi, Bír 1, 30).

1590: ne légyen se része se o̊róksége az to̊b Izraellel, hanem az WRnac tüzes áldozatit és o̊rókségét egyéc (vizsolyi, 5 Móz 18, 1).

1626: Ne légyen a'papoknak, és Levítáknak, és mind abbóla'nemzetségbo̊lvalóknak, részek és o̊rókségek a’ to̊bb Israëllel, mert az Úr áldozatit és ajándékit észik (Káldi).

1519 k.: se tennen feyedre ne eskwgyel [...] Legyen azert ty bezettek: vğ, vğ, nem, nem (JordK., Mt 5, 36-37).

1541: se az te fedre ne eskeǵgēl [...] De ez legyen a tù beszidetek vǵ vǵ nem nem (Sylvester).

1519 k.: kyk magokat zydoknak mongyaak, de nem azok, mert hazwdnak (JordK., Jel 3, 9). 
1590: kic mondgyác magokat Sidóknac, maga nem azoc, hanem hazudnac (vizsolyi).

Szintén nem ritka, hogy az egyik forrásban ellentétként jelenik meg az adott tartalom, míg a másik fordítás ugyanezt valamilyen határozói körülményként adja vissza (cél, idő stb.):

1590: Nem üzỏm ki òket az ti ortzátoc elồl, hanem lésznec mint tôuissec az ti óldalatokba (vizsolyi, Bír 2, 3).

1626: Az-okáért nem akartam ò ket el tỏrleni színetek-elôl: hogy légyenek ellenségitek, és azok isteni légyenek romlástokra (Káldi).

1590: Es ne nézzetec az ti sziuetec vtán, és az ti szemeitec vtán, a mellyec vtán ti paráznalkodtoc. Hogy meg emlekezzétec (vizsolyi, 4 Móz 15, 39-40).

1626: és ne kôvessék az o̊ gondolattyokat, és szemeket, kủlo̊mb-kủlömbféle dolgokkal paráználkodván, hanem inkább emlékezvén az Úr parancholatiról (Káldi).

1519 k.: nem tehet az ffyw ennen magatwl valamyt, $k y t$ latangya hw attyat tenny (JordK., Jn 5, 19).

1590: hogy ném czelekedhetic a' fiu o o magától, hanem ha látandgya az atyat teelekedni (vizsolyi).

1519 k.: ne lathwan hw" halalat, hanem elezer lathnaa vrnak (JordK., Lk 2, 26).

1590: hogy halált nem látna addig, mignem meg látná az Wrnac amaz Chriftufát (vizsolyi).

A variáció részben az esetleges eltérő szövegelőzményekkel magyarázható, illetőleg a figyelemirányítás eltérő tendenciáival.

\section{Kontraszt és/vagy kapcsolat: tendenciák az explicit-implicit kifejezésmód kapcsán}

Az ellentét mindhárom funkciója napjainkban is kifejeződhet kapcsolatos és kötőszóval (Balogh 2000: 536-8). A bibliafordításokban az indirekt elvárásokra épülő ellentét jellegzetes - tipikusan verseket összekötő - retorikai megoldás, föként a Jelenések könyvében. Az alábbi példa minden vizsgált párhuzamos szövegben hasonlóan fejeződik ki: az előzményből kiderülnek az adott terület lakóinak erényei, a folytatás azonban - az ez alapján kialakuló elvárással szemben - nem arról tudósít, hogy Isten teljesen elégedett velük (azaz nincs félnivalójuk). Ezt követően azonban kiderül, hogy az ellenkezőjét sem kell feltételezni, fenntartva a bizonytalanságot:

1590: De vagyon valami ellened való mondásom, mert az te elsỏ szeretetedet el hadtad [...] De ez ió benned, hogy az Nicolaitáknac tselekedteket gyù lòlted (vizsolyi, Jel 2: 4-6). 
Jóllehet a történeti szövegektől egészen máig jellemzö, hogy az ellentét bármely fajtája kifejeződhet kapcsolatos kötőszóval, az azonban kérdés, hogy a bibliai szövegekben milyen megoszlás mutatkozik ezen a téren. További szempont, hogy milyen pragmatikai tendenciára lehet ebböl következtetni a kontextuális helyénvalóság és a kontextus felülírásának összjátékát tekintve (ajánlott értelmezés, proffered interpretation; Roberts 2004: 209-10), azaz törekednek-e az egyes fordítások az egyértelmüségre a kötőszóválasztás által, vagy inkább a nyitott értelmezést preferálják. A két tendencia együtt is jelentkezhet:

1590: keresic az emberec az halált és nem talállyác meg azt, és kéuánnánac meg halni, de az halál el mégyen elôttoéc (vizsolyi, Jel 9, 6).

A zéró kötőszóval való variáció a vizsgált anyagban összesen 88 szöveghelyen érinti a fordítások valamelyikét (újszövetségi: 30; ószövetségi: 58). Történetileg alapvető volt a kötőszó nélküli mellérendelés - a tartalmi viszonyok számos értelmezési lehetőségével -, és más forrásokban, például a kései ómagyar levelekben is jellemző volt a kötőszóhiány (Papp 1995: 727). A biblikus szövegekben ehhez képest meghatározó a mellérendelő kötőszók jelentős száma (bár főként a kapcsolatosak). Ezen a téren a vizsolyi biblia és a Káldi-féle fordítás hasonlónak mutatkozik, legalábbis a számarányokat tekintve közel azonos arányban fordul elő náluk az egyes viszonyok implicit jelölése (valamivel több mint az esetek felerészében).

Az ószövetségi szövegek képe változatosabb, mint az újszövetségi; a vizsolyi biblia hanem használata kisebb arányú, mint a Káldi-féle fordításé. Ez azonban nem azért van, mert az archaikusabb de kötőszó jelenik meg, inkább hajlamos implicit maradni ez a viszony:

1590: Nem esset el czak egy beszédis, mind abból az ió beszédből, mellyet szólótt vala az WR az Izrael házánac: Mindenec meg lỏnec (vizsolyi, Józs 21, 45).

1626: Chak egy ige sem lôtt abban heában mellyet fogadott vala hogy bétellyesítene, hanem valósággal mindenek bé-tellyesedtek (Káldi).

1519 k.: te sem meegh be oda, $D e$ Josue Nwn ffya az the zolgaad, ew megyen (JordK, 5Móz 1, 37-38).

1590: Te sem mégy oda be. Az Iosue az Nun fia, aki áll te elötted, o̊ mégyen be oda, azért òtet biztassad (vizsolyi).

1626: Te sem mégy-bé oda, hanem a’ Nun fia Hósue a’ szolgád, o̊ mégyenbé éretted (Káldi).

A hanem hiánya nem okoz nehézséget a megértésben, hiszen a legtöbb esetben az első tagmondatban tagadás utal a kizárásra:

1541: el nem tavozik vala az Templombol / büytöliesekben es imadsagokban magat foglalta vala (Sylvester, Lk 2, 37).

1590: nem táuozic vala el az templomtól, hanem éijél és nappal szólgál vala Istennec (vizsolyi). 
A témaváltás jelzését a vizsolyi bibliában a központozás hangsúlyozza, míg később ezt a funkciót is átveheti a hanem:

1519 k.: masnak attam ewteth, de egy hwga vagyon, ky zep ewnalanal (JordK., Bír 15, 2).

1590: annac okaért adám o̊tet az te társodnac: Az o o òcze nem de nem szepbé annál (vizsolyi).

1626: és azért adtam o̊tet [...] hanem vagyon o̊̀ttse, mely ifiabb (Káldi).

Jellemző továbbá a kapcsolatos kötőszó gyakori előfordulása már az ómagyar biblikus szövegekben is. Ezt általában a fordítás sajátosságának tartja a szakirodalom: hebraizmus a latin megfelelök közvetítésével (Juhász 1992: 802; Haader 2018: 220). Minél változatosabb jelentésủ egy mellérendelő kötőszó, annál inkább hajlamos más típusokkal érintkezni, így az és különösen sokfunkciósnak számít a korszakban, az ellentét fajtái közül a szembeállítás és a kizárás kifejezésére használatos (Haader 2018: 220-1). Ez kimutatható a középmagyar bibliafordításokban is (az átjárhatóságot a szerkezetek közötti variáció is mutathatja):

1590: nem hagya élôt, és minden lelket meg o̊lé (vizsolyi, Józs 10, 40).

1626: nem hagya abban semmi maradékot, hanem mindent a'mi lehelhet vala meg-o̊le (Káldi).

1590: Ti pediglen legyetek vtánoc az ti ellenségteknec és az ö vtóliáróiokat vágiátok és ne boczasságtoc be öket (vizsolyi, Józs 10, 19).

1626: tí pedig ne állyatok, hanem kergessétek az ellenséget, és a szaladóknak utól-járóját vágton vágjátok (Káldi).

A vizsgált párhuzamos források sem törekszenek ugyanakkor mindig a kizárás egyértelmü jelölésére (ezúttal épp a vizsolyi jelöli expliciten):

1519 k.: es nem tọ́rlyọ́m ky ew neveeth az eelew kenybọ́l, es vallom ew neveeth en atyamnak (JordK., Jel 3, 5).

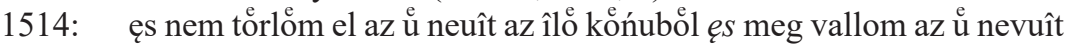
(Sylvester).

1590: és el nem tỏrlòm annac neuét az életnec kơnyuébỏl, hanem vallást tészec annac neuérôl (vizsolyi).

1626: és ki nem tơrlo̊m az o̊ nevét az Élet-kỏnyvébo̊l, és meg-vallom az o̊ nevét (Káldi).

Az ószövetségi szöveghelyeket tekintve ugyanakkor Káldi fordítása mutatkozik explicitnek ezen a téren - legalábbis a vizsolyi bibliához képest, bár jelentősebb menynyiségi különbségekröl nem beszélhetünk (az eltérés a zéróval és az és-sel történö variálódáskor mutatkozik), ráadásul a két forrás a legtöbb esetben „kiegészíti egymást": ha az egyik implicit megoldást választ, a párhuzamos szöveghelyen kötőszósat. Ez szabad váltakozásra enged következtetni, a viszony implicit voltának pedig, a központozás alapján következtetve, retorikai szerepe lehet a vizsolyi bibliában. 
Az explicit-implicit kérdéskör mentén további szempont a kapcsolatos kötőszó ellentétet kifejező használata. Az értelmezést tekintve az és, illetőleg a de kötőszós szerkezetek hasonlóan sokrétüek, többféle konvencionális implikatúrát képezhetnek (hasonlóan az igeneves szerkezetekhez, vö. Gugán 2002: 38-9, 1. még Varga 2017). A kapcsolatos viszony és a szembeállítás különösen átjárható kategóriának minősül: „A kapcsolat és a szembeállítás (az ellentét legenyhébb formája) jelentésbelileg igen közel állnak egymáshoz" (a meg kötőszó kapcsán Haader 2003: 688; Papp 1995: 481). Megszorító ellentétként ugyanakkor az és inkább a kötőszói funkció megerősítéseként társul az újabbakkal (Haader 2003: 689). Az itt összevetett bibliafordítások ugyanakkor azt a tendenciát mutatják, hogy a megszorító de az és ellentétet kifejező használatával igen gyakran variálódik (a vizsgált anyag újszövetségi részében 99 szöveghelyen, az ószövetségiben 41 alkalommal). Mind a négy fordításban egyazon megoldással élnek a következő példában:

1519 k.: Azok kedeg nem ertyk vala e bezeedet es feelnek raytta hwtet megh kerdeny (JordK., Mk 9, 32).

1541: Ęs ůk nem tugǵak uala mit mondana es nem merik vala ůtet meg kerdeni (Sylvester).

1590: O̊k pedig nem értic vala ez mondást, és félnec vala òtet meg kérdeni (vizsolyi).

1626: O̊̉k pedig nem értik vala az igét, és félnek vala ö́tet megkérdeni (Káldi).

Ugyanakkor nem lehet teljes következetességet feltételezni egyetlen forráson belül sem, noha az evangéliumok közötti tartalmi megfelelés akár ezt lehetővé is tenné (az első adat teljes megfelelést mutat a párhuzamos fordításokkal, a másodikban a vizsolyit kivéve mind az és-t alkalmazza):

1590: Mert el iôtt az esso̊ , el io̊tt az ár víz, el io̊ttec az szelec, meg ůtkơztec az házba, és nem romlott el (vizsolyi, Mt 7, 25).

1590: minec vtánna pedig el iơtt az ár víz, meg ủtkỏzo̊tt az folyó viz abba, de azt meg nem mozdithatta (vizsolyi, Lk 6, 48).

A források közötti legmarkánsabb különbség ezen a ponton rajzolódik ki, föként az újszövetségi részek alapján. A vizsolyi biblia a kigyüjtött szöveghelyek több mint háromnegyedében (77\%) megszorító kötőszót használ, egyértelművé téve a kifejezni kívánt viszonyt (az ószövetségi anyag kisebb arányt mutat a de javára, $60 \%$ alatt, ugyanakkor jelentősen kevesebb a szöveghely is). Sylvester és Káldi fordításában éppen fordított az arány: az előbbi 74\%, míg az utóbbi 80\%-ban és-sel kapcsolja ezeket a helyeket (Káldi fordításának ószövetségi részeiben az arány szintén $60 \%$ alá csökken). A JordK. esetében kevésbé kiugróak az arányok, de valamivel több mint a szöveghelyek felében szintén a kapcsolatos megoldás szerepel. Különösen tendenciaszerünek mutatkozik a vizsolyi biblia eltérő, a megszorító ellentétet explicit kötőszóval is kihangsúlyozó megoldása a Jelenések könyve 12-13. fejezetében. 
A többi három fordításban közös, hogy az alábbi példákban és-sel fejezik ki az ellentétet - ezúttal ezek közül csak Káldi fordítását idézem (az eddigieknél nagyobb kontextussal):

1590: Es lo̊n az egben nagy viaskodás Az Mihál és az o̊ Angyali viaskodnac vala az sárkánnyal, és az sárkánis tusakodic vala, és az ò Angyali. De nem veheténec diadalmat, és az ò helyekis tỏbbé nem találtatéc menyben (vizsolyi, Jel 12, 7-8).

1626: És nagy harcz lợ az égben: Mihály, és az o̊ Angyali harczolnak vala a' sárkáñyal, és a' sárkány harczol vala és az ò Angyali: és nem vehetének erôt, se helyek nem találtaték azoknak tỏbbé az égben (Káldi).

A fenti példában a kontextus világos a szövegelőzmény miatt, az elvárásokat pedig meghatározzák a befogadó általánosabb tudása, vélelmei. Az előfeltevések és elvárások tehát indirektek: a szereplők megnevezésének sorrendje, valamint a harc, a tusakodás megismétlése (és másodjára nyomatékosan a sárkányhoz kapcsolása) miatt implikálódhat a sárkány lehetséges győzelme (a hívő olvasói számára akár elővetítve ennek minden lehetséges negatív következményét). A folytatás azonban nyilvánvalóvá teszi a sárkány tusakodásának eredménytelenségét - a megszorító ellentét ezt közvetlenebbül hozzáférhetővé teszi a befogadó számára (annak rendkívüliségére is irányítva a figyelmet), mint az első pillantásra inkább időbeli rákövetkezést kifejezőés. Ezutóbbinál a kontextus felülíródik a szituáció ismeretében (bár az és 'és mégis/mégsem' értelemben jelezhet szokatlanságot, váratlanságot). A további példák hasonlóan müködnek, újra és újra elörevetítve a Napba öltözött asszonyt fenyegető veszélyeket:

1590: Mikor azért látta vólna az sárkány hogy le vettetet vólna az fóldre, kergetni kezde az aszoni állatot melly az fiat szủlte vala. De adattatánac az aszoni állatnac ket nagy sas szárnyác, hogy az sárkány elôtt el repuelne az puztába az ö helyére, hogy tápláltasséc ott ideig (vizsolyi, Jel 12, 13-14).

1626: És minek-utánna látá a' sárkány hogy levettetett vólna a' fôldre, kergeté az aszszony’állatot, melly a'fiú magzatot szủlte: és adatának az aszszony’állatnak két nagy sas szárnyak, hogy a’ pusztába rôpủlne az ơ helyére, a' hol tápláltatik ideig és idôkig (Káldi).

1590: Es botsáta az kigyó az o̊ száiából az aszoni állat vtán v’gy mint folyó vizet, hogy azt azzal el ragadtatna. De segitségủl lòn az föld az aszoni állatnac, és meg nitá az fôld az o̊ száiát, és el nyele az folyó vizet, mellyet az sárkány az o o száiábol botsátott vala (vizsolyi, 12, 15-16).

1626: És a’ kígyó a’szájából az aszszony’állat-után mint egy folyó-vizet bocháta, hogy òtet el-ragadtatná a’ folyó-vízzel. És meg-segété a' fóld az aszszony'állatot, és meg-nyitá száját a' fôld, és el-nyelé a’ folyóvizet, mellyet a sárkány a’ szájából bochátott vala (Káldi). 
Az és-t, illetve a de-t követö következö tagmondatok minden esetben érvénytelenné teszik az előzményből indirekt módon következö, implicit elvárást, a folytatás pedig hangsúlyozza ezt:

1590: Meg haragodéc azért az sárkány az aszoni állatra, és el méne hogy hadakoznéc egyebeckel (vizsolyi, 12, 17).

A továbbiakban hangsúlyos a két esemény/helyzet együtt járásának szokatlan, rendkívüli volta - a halálos seb már a jelző megválasztásával elörevetíti a halált mint legvalószínúbb következményt. Ezt az elvárást azonban törli a folytatás, a legvalószínütlenebb következményröl számolva be (vö. csodálkozék); máshol pedig a látszattól eltérést jelezve:

1590: Es látám hogy egy az o̊ feiei közzül v'gy mint halálos sebbel meg sebesitetett, de az ò halálos sebe meg gyogyitatéc (vizsolyi, 13, 3).

1626: És láték eggyet a'fejei-kơzzủl mint-ha halálra o̊lettetett vólna meg: és az ò halálos sebe meg-gyógyíttaték. És chodálkozék az egész fôld a'fene-vad-után (Káldi).

1590: Es látéc más fene vadat feliơni az földböl, kinec ket szarva vala, mellyec az báránnac szarvához hasonlatosoc valánac, de vgy szól vala mint az sárkány (vizsolyi, 13, 11).

1626: És láték más fenevadat fel-jồni a’ fôldröl, és két szarva vala hasonló a’ Bárány szarvához, és szóll vala mint a’ sárkány (Káldi).

A vizsolyi biblia ezen a téren inkább az értés és megértetni akarás (a kontextusnak közvetlen megfeleltetés) elvét érvényesítni, a kötőszóválasztással ráirányítva a figyelmet a majdani elvárásokra és azok felfüggesztésére vagy érvénytelenségére. A többi fordításra a biblikus szövegekben hagyományosabb és használat a jellemző, valószínüleg inkább a szöveghez tapadó fordítást helyezve előtérbe, az ezzel együtt járó nyitott, közvetett értelmezéssel együtt.

Az ellentét viszonya kapcsolatos kötőszóval kifejezve, illetőleg a kétféle kifejezésmód váltakozása ugyanakkor nemcsak a fordításokra jellemző; az eredeti, magánéleti regiszterből származó szövegekben - levelekben, tanúvallomásokban - sem példátlan a Történeti magánéleti korpusz alapján. Elsősorban a megszorító utótagú ellentétre és a szembeállító ellentétre adatolható a váltakozás:

1591: Egikor pap lukacine ker vala tulem vajat, es nem adek ismet ez utan ker vala tulem penzt, es nem adek es hortelen olj niaualiam len, hogj ciak meg nem halek (Bosz. 15.).

1730: vas rostat jött kérni de nem adtunk néki (Bosz. 79.).

1717: Látta a fatens Szücs Annát a Biro János háza alatt állani, mikor a kutyallyat kergettik, es onnet hová ment nem tudgya (Bosz. 31. ).

1717: Hogy a kutyallyat ki kergettette Szücs Anna, a fatensnek ott font egy kevesse, onnal el ment de nem tudgya a fatens hova (Bosz. 31.).

2 A Történeti magánéleti korpuszból származó adatokat a kötetek alapján betűhủen közlöm (http://tmk.nytud.hu/forrasok.php), a hivatkozás a forrás korpuszbeli rövidítése és a perszám, levélszám alapján történik. 
1579: de ez vtan Sulyok Istwannak Ismerd Lenj es nem Baratodnak tarchad (Tel., 110.).

1653: hasznal nekie, azert kirte őis, es nem mas gonosz uigre (Bosz. 457).

1708 nem hijába késnek vele, mivel ez után Károlyban leszen az posta, és nem Szathmárt (Kár. 81.).

1712: továb is engedje Isten, én adhassak nekik és nem ők nekem (Kár. 130. ).

A nem pedig változatra az adatbázis mindössze két adatot tartalmaz, azokat is a 18. századból: 1716: tehát az Baba hivta a fatenst Komának, nem pedig Veres Nagj Jánosnét (Bosz. 61.); 1751: ennek elötte cir. 7 Esztendövel lévén a Fatensnek Felesége nyughatatlanságban, hogy egesz Éczakais kellett néki vigyázással nem pedigh nyugodalommal el tölteni (Bosz. 328.). A szembeállítást így kifejező megoldás tehát a korpusz (és a vizsgált bibliafordítások) alapján a korszak jellemzője - noha a későbbiekben sem teljesen példátlan.

\section{Adalékok a kizáró ellentét alakulástörténetéhez és variációjához}

A hagyományos leírásban a kizáró használat képviseli a legerősebb ellentétet. Pragmatikai/funkcionális megközelítésben viszont vitatott a megítélése, Hadrovics szerint teljesen eltérő kategóriába sorolható, mint a megszorító (1969: 179-80), míg Bratinka szerint az implikációkat tekintve kapcsolat van közöttük (1987: 24-6). A kizáró de, illetőleg hanem által összekapcsolt tagmondatok két külön állításra vonatkoznak, így mindkét tartalom érvényes maradhat anélkül, hogy együtt ellentmondást eredményezne, míg a megszorító funkciónak része az ellentmondás, és annak az implicit elvárásnak a felfüggesztése, hogy az adott két cselekvés, történés jellemzően nem jár együtt. A két tagmondat tartalmának együttes érvényessége természetesen azzal függ össze, hogy az első tagmondatból nem törölhető a tagadás anélkül, hogy a kifejezni kívánt viszony megváltozna (a formával együtt, vö. nemcsak..., hanem... is). Az előző tagmondatban egyéb nem stb. típusú szerkesztés ,szinte maga után vonja" a 'de egy bizonyos dolog igen' értelmü folytatást (Juhász 1991: 492-3, 1992: 795; Papp 1995: 730, 734-5). A hanem a 16. század során váltja fel a de-t ebben a funkcióban. Erre alkalmassá teszi az elsődlegesen kiemelő, megkülönböztető funkciója, illetőleg annak átértékelödése 'hanem csak' > 'csak, kizárólag'.

$\mathrm{Az}$ újabb kötőszó térnyerésének fokozatos volta mind a négy vizsgált forrásban megmutatkozik:

1519 k.: Lassad hoğ senkynek ne mongyad; de meny el (JordK., Mt 8,4).

1541: Meglāssad hoǵ valakinek ne monǵad de menń el (Sylvester).

1590: meg lásd hogy senkinec ne mondgyad hanem meny el (vizsolyi).

1590: annac okaért mostan nem nyúlhatunk hozzáioc. De ezt czelekedgyüc vélec, (vizsolyi, Józs 9, 20). 
1626: és azért nem nyúlhatunk hozzájok. Hanem ezt chelekedgyük nékik (Káldi).

A következő táblázat azt mutatja meg, hogy az egyes forrásokban mennyire gyakori a hanem előfordulása. A Biblia két fő részét egyrészt a források közötti nem teljes átfedés miatt vettem külön, másrészt így az esetleges különbségek mintázatai jobban megfigyelhetök. A szöveghely ezúttal azt jelzi, hogy összesen hány helyen fordult elö kizáró ellentét (függetlenül attól, hogy csak az egyik vagy csak a másik forrásban, míg a többiben nem).

3. táblázat. A hanem előfordulási gyakorisága forrásokra lebontva

\begin{tabular}{|c|c|}
\hline JordK.: 11 & JordK.: 41 \\
\hline- & Sylvester 149 \\
\hline vizsolyi: 76 & vizsolyi: 166 \\
\hline Káldi: 96 & Káldi 163 \\
\hline ÓSZ-szöveghely: 102 & ÚSZ-szöveghely: 187 \\
\hline
\end{tabular}

A kifejezőeszközök szerinti variációról elmondható, hogy JordK.-nél későbbi fordításokban elöforduló hanem-ek aránya kiegyensúlyozottabb képet mutat az újszövetségi anyagban, mint az ószövetségiben. Ebböl az is látszik, hogy Sylvester fordítása ezen a téren inkább a vizsolyi bibliával és Káldi fordításával mutat hasonlóságot, kevésbé jellemző rá az archaikusabb de használata. A JordK. az esetek mintegy 78\%-ában választja az archaikusabb megoldást (az ószövetségi anyag esetében a szöveghiányok miatt nem egyértelmü az arány).

Mivel a vizsgált anyagban összesen 52 esetben mégis a többi fordításnak megfelelöen az újabb kapcsolóelem szerepel a szövegben, kérdés, hogy ennek alapján kirajzolódik-e valami korlát, szempont a változatok közötti választásról, illetőleg az újabb változat térnyeréséről. Néhány példa a forrásokkal való teljes megfelelésből:

1519 k.: nem valanak ffyay hanem czak leany (JordK., Józs 17, 3).

1519 k.: Nem az my reghy atyankkal, hanem my velwnk (JordK., 5 Móz 5, 3).

1519 k.: nem nylwan, hanem oly mynt tythkon (JordK., Jn 7, 10).

1519 k.: Nynczen kyralywnk, hanem czazarwnk (JordK., Jn 19, 15).

1519 k.: meg ne serteneek az zóld fyweketh, se faakat, hanem czak embereketh (JordK., Jel 9, 4).

E részletek alapján arra következtethetünk, hogy ha alanyra vagy a leírt esemény egyéb körülményére vonatkozik a tagadás (és így a kizárás), akkor megjelenik a hanem is. Az eddigi adatok azonban nem utalnak arra, hogy ez az állítmánnyal kapcsolatos kizárásra is jellemző (a többi fordításban e helyen hanem szerepel, egyet idézek):

1519 k.: ne ellene allany az gonoznak. De ha ky arczwl ytendy yob arczadat (JordK., Mt 5, 39). 
1590: hogy az gonosznac ne állyatoc ellene (gonoszszal) hanem az ki téged iob felòl artzul ůtend (vizsolyi).

1519 k.: nem vagok melto hog be yew en haylokom ala, de czak mongyad ygheeddel (JordK., Mt 8, 8).

1626: Urā nē vagyok mélto hogy hajlékōba jốj: hanē chak egy szóval mōgyad (Káldi).

A fenti esetben Sylvester fordítása annyiban mutat különbséget, hogy a kizáró ellentétet a sőg ('sőt') fejezi ki. Az állítmánnyal kapcsolatban kirajzolódó szerkezeti korlát az ószövetségi részletekben is megfigyelhető:

1519 k.: Nem megyek el teeveled. De az en zyleteesemnek feldere terók (JordK., 4 Móz 10, 30).

1626: Nem megyek-el veled, hanem meg-térek fốldembe (Káldi).

1519 k.: Es nem akaratok ew belee zallany, De hytetlenek leetek wr ystennek zawara (JordK., 5 Móz 1, 25).

1590: Es mind azáltal nem akarátoc fel menni, hanem ellene tusakodátoc (vizsolyi).

Jellemző ugyanakkor a JordK.-re a hanem használata annak archaikusabb, kiemelö, megkülönböztető funkciójában (Haader 2003: 688-9). Ez a használat viszont időnként jelöltebb formában figyelhető meg itt, mint a többi fordításban:

1519 k.: Ystenth soha senky nem latta; hanem czak hẅ eggethlenee (JordK., Jn 1, 18).

1541: soha senki nem latta. Az eggetlen egg fiu ki az at'ānak kebeliben vaǵon ü hirdette ki (Sylvester).

1590: Istent soha senki nem látta, amaz eggyetlen egy szůletet fiu ki az atyánac kebelében vagyon, az beszéllette meg mi nékünc (vizsolyi).

1626: Az Istent soha senki nem látta: az eggyetlen-egy szůletett fiú, a’ki az Atyának kebelében vagyon, o̊ beszéllette-meg (Káldi).

A megkülönböztetés, kiemelés a későbbi forrásokban hajlamosabb mondatrészértékü formában, például ragvonzó névutós szerkezetben megjelenni:

1519 k.: Egy waras sem leeletteteek, ky Izraelnek megh nem holdolt vona hanem czak az eweus (JordK., Józs 9, 19).

1590: Nem vólt olly város ki békeséget tett vólna az Izrael fiaiual, az Hiueusoktól Gibonnac lakoitul el válua (vizsolyi).

1626: Nem vólt olly várás melly meg-adná magát [...] Hevaeustól megválva (Káldi).

1519 k: Senky nem lattya ez nemzethseeghbely nepek kezzól az yo fledet [...] hane’ czak kaleb (JordK., 5 Móz 1: 35-36). 
1590: eggyis nem láttya az ió földet, [...] Az Chalebtöl Iephune fiától megválua (vizsolyi).

1626: Nem fogja eggy-is látni [...] Kálebtôl meg-válva (Káldi).

Az újszövetségi forrásokban még a kötőszó eredetét felidézö, feltételhez kapcsolt megkülönböztetés (kiemelés), kizárás jellemző:

1519 k.: hanem ha ky wyonnan zyletendyk masodzer, nem lathatt"a ytennek orzagat (JordK., Jn 3,3).

1590: ha valaki vijonnan nem szůletendic, nem láthattya az Istennec országát (vizsolyi).

A négy elemzett fordítás közül a JordK. örzi leginkább a hanem archaikusabb funkcióit (nem egyszer a leginkább explicitté téve ezeket), miközben a kizáró ellentét terjedésének folyamatát is mutatja. Úgy tünik, az, hogy az archaikus vagy az újabb kötőszó fejezi-e ki a kizáró ellentétet, attól függ, hogy az adott elem a mondat mely részére vonatkozik. Az adatok alapján legalábbis az állítmányt követően jelenhetett meg legkésőbb a kötőszó újabb szerepben - a kérdés természetesen kutatást igényel a teljes anyagon, illetőleg más források bevonásával.

Ahogy arról már volt szó, a megszorító és a kizáró ellentét közötti átjárhatóság vitatottnak tekinthető, mivel az első esetben felfüggeszthető az az elvárás, hogy a két cselekvés/állapot hagyományosan nem jellemző együtt, míg a másodikban az együtt előfordulás expliciten tagadva van. Éppen ezért kérdés, hogy a párhuzamos szöveghelyeken a kizáró funkciójú de egyszerüen az archaikus változat választását jelenti, vagy megszorító értelmü is lehet, megengedve az ellentmondást. Az alábbi esetben a lehetséges ellentmondás lényegében a megszólítottak tudására vonatkozik, így általánosabb értelmű, mint a jelzett cselekvések:

1519 k.: es en magamtwl nem yettem, de vagyon ygaz ky enghem boczatot kyt thy nem twttok (JordK., Jn 7, 28).

1541: ęs en magamtul nem iứttem hanem igaz az ki enghemet el boczāta [...] (Sylvester).

1590: és én magamtól nem iôttem, de igaz az ki engemet el kủldütt, kit ti nem esmértec (vizsolyi).

1626: és én magamtól nem jöttem, de igaz az ki engem kủldo̊tt [...] (Káldi).

A további alternatív kötőszóválasztás szintén a megszoritó-megengedő jelentés felé elmozdulás lehetőségét veti fel:

1519 k.: ty reatok eegyeb terhet nem boczatok; de maga, myben vattok meg tarczatok (JordK., Jel 2, 24-25).

1541: nem eresztek tů reatok egyeb terhet / de maga tarczātok azt az mell' vaǵon (Sylvester). 
1590: nem vetec reátoc más terhet. Hanem az melly nállatoc vagyon, azt tartsatoc meg (vizsolyi).

1626: nem vetek rátok más terhet, mindazáltal azt, a'mi nálatok vagyon, tartsátok-meg (Káldi).

Az alábbi részlet nemcsak a váltakozó kötőszóhasználatot mutatja, hanem a megszorító és a kizáró ellentét közötti átjárhatóságot, illetőleg szerkezeti variációt, a tagmondatok sorrendjének (illetőleg lineáris és beékelést tartalmazó változatát) is beleértve:

1519 k.: az byneseket ysten megh nem halgattya, de ha ky ysten feelọ lëend, es ky hẅ akarattyat teezy, az ollyant hallgattya meg (JordK., Jn 9, 31).

1541: az bunósókôt isten meg nem hallgatta, hanem azt hallgatt'a meg az ki isten filo ember (Sylvester).

1590: az Isten a' bunôseket meg nem halgattya, De az ki az Istent tizteli, és az ̊ akarattyát tselekeszi [...] (vizsolyi).

1626: a' bưnòsóket az Isten meg nem halgattya: de a' ki Isten-tisztelò, és az ö akarattyát chelekeszi [...] (Káldi).

A párhuzamos szöveghelyek máshol is olyan mértékü átjárhatóságot mutatnak, ahol a tagmondatsorrend is eltérő lehet - ez föként az ószövetségi részekre jellemző:

1590: kezekben adunc tégedet ö nekiec, de meg nem ölünc tégedet (vizsolyi, Bír 15: 13).

1626: Meg nem ölünk téged, hanem kötve kézbe adunk (Káldi).

1590: Az idegennec adgy vsurára, de az te atyádiánac vsurára ne adgy (vizsolyi, 5 Móz 23: 20).

1626: ne adgy uzorára az atyád-fiának [...] hanem az idegennek (Káldi).

A bibliafordításokat tekintve tehát a kérdés mindenképpen összetett, és egyelőre nem válaszolható meg határozottan. Mindenesetre a korszak magánéleti regiszterében sem példátlan (a Történeti magánéleti korpusz adatai alapján), hogy az állítmányra vonatkozó kizáráskor a de jelenik meg:

1538: En nem tiltlak !hg oda ala Ne Mennil a Jozagba, de chak ezt mondom (Svetk., 2.).

1584: Akkor elmene, és nem láttam, de hallottam, hogy azutánn is kétszer is jött késen oda (KBosz., 24.).

1591: Ezon azzonni azt monta az en uram nekom germekot nem cinalhatot volna, de nagj balas cinalta (Bosz. 15.).

Az adatok száma azonban nem elégséges ahhoz, hogy az eredeti szövegek alapján határozottabb megállapítást tegyünk arra vonatkozóan, hogy a kizárás hatóköre ténylegesen befolyásolja-e az újabb változat terjedését. 


\section{6. Összefoglalás}

Az ellentétes mellérendelés kifejezőeszközeinek és funkcióinak variációja számos területen megmutatkozott a JordK., a vizsolyi biblia, valamint Sylvester és Káldi fordításainak összevető elemzése során. A variáció egy része változáshoz kapcsolódik, más része pedig a különféle nyelvhasználati sajátosságokról (például a kontraszt párhuzama más körülményekkel, például oksággal kifejezve vagy a szembeállító és nem használata) nyújt pillanatképet - kitekintve a magánéleti regiszterre is.

Az egyik változás a kifejezőeszközök használatában a kizáró ellentétet érinti. Ezen a téren a fokozatosságot sikerült érzékeltetni, mivel egy-egy szöveget vizsgáltam részletesen egy-egy időszakból. A JordK. adatai alapján a kapcsolóelem „hatókörének” szerepe lehetett az újabb változat terjedésében. Ahogy várható volt, a JordK. a többi forráshoz képest archaikusabb ezen a téren, miközben Sylvester nem sokkal későbbi fordítása az újabbakhoz hasonlít. A vizsolyi biblián belül is mutatkoznak különbségek a kizáró viszony kifejezésében, ebben azonban föként az explicit-implicit, (illetőleg közvetlen-közvetett értelmezés), azaz a zéró vagy az és kötőszó, valamint (több forrásban is) az egyéb, például oksági viszonyok játszanak szerepet. A magánéleti regiszterre való kitekintés alapján a 16. század második felében sem példátlan az archaikusabb de-vel kifejezett kizáró ellentét, a hatókört illetően azonban további kutatások szükségesek.

Markáns variáció mutatkozott a megszorító ellentét kifejezésében, az ellentét, a megengedés és a kapcsolatos viszony elhatárolását is felvetve (a magánéleti regiszter alapján általánosan a korszak jellemzőjeként). Ezen a téren két szélsőséges tendencia rajzolódott ki, ezek külön forrásokhoz is köthetök (föként az újszövetségi fejezetek alapján): a vizsolyi biblia (és kisebb részben a JordK.) esetében a megszorító ellentétet a kötőszóválasztás által rendszeresen egyértelmű formában fejeződik ki, irányítva a figyelmet: ezt az értés-megértetés szándéka motiválja, az egyértelmüségre törekvés. Káldi és Sylvester fordításában ezeken a helyeken is elsődlegesen a sokfunkciós és jelenik meg (az ómagyar fordításokhoz hasonlóan), csak ezeket olvasva a tartalmi viszonyok többféle - a szövegelőzmény és a világról való tudás alapján felülírható - értelmezése is lehetséges, ez ugyanakkor feldolgozás közvetettségével jár. A forrásszöveg sajátságosnak bizonyult annyiban, hogy az ószövetségi és az újszövetségi részek az egyes fordításokon belül is eltérö tendenciákat mutathattak, nem egyszer a szerkezetbeli variációt is beleértve.

\section{FORRÁSOK}

JordK. $=$ Jordánszky-kódex 1519. k. Régi magyar nyelvemlékek. 5. Közreadja: Toldy FerencVolf György. Magyar Tudományos Akadémia, Budapest.

Káldi $=$ Káldi György. Szent Biblia. Bécs. 1626. [Hasonmás: Faximilex Kiadó, Budapest, 2002.]

Sylvester $=$ Sylvester János. Uy Testamentu magar nelwen mellet az Görög és Diak nelvböl uyonnan fordijtank, az Magar nipnek Kereszten hütben valo ippülisire. Sárvár, 1541. [Hasonmás kiadás Kossuth, MTA KIK, Budapest, 2017.]

TMK = Történeti magánéleti korpusz (http://tmk.nytud.hu/).

vizsolyi = Károlyi Gáspár. Szent Biblia. Vizsoly. 1590. [Hasonmás kiadás: Magyar Helikon, Budapest, 1981.] 


\section{SZAKIRODALOM}

Balogh Judit 2000. A mellérendelő összetett mondatok. Az ellentétes mellérendelés. In: Keszler Borbála (szerk.): Magyar Grammatika. Nemzeti Tankönyvkiadó, Budapest, 536-38.

Bratinka József 1987. De, hanem, hogynem. Pragmatikai megközelítésben. Néprajz és Nyelvtudomány 31-32: 21-41.

Dömötör Adrienne 2003. Szinonim mondatszerkezetek és formai változatok. Vonatkozó mellékmondatos alárendelések és párhuzamaik hat korai bibliafordítás tükrében. Magyar Nyelv 99: 448-66.

Dömötör Adrienne - Gugán Katalin - Novák Attila - Varga Mónika 2017. Kiútkeresés a morfológiai labirintusból - korpuszépítés ó- és középmagyar kori magánéleti szövegekből. Nyelvtudományi Közlemények 113: 85-110.

Gugán, Katalin 2002. Syntactic Synonymy: A case study. Acta Linguistica Hungarica 49: 23-49. https://doi.org/10.1556/ALing.49.2002.1.4

Haader Lea 2001. Mikrodiakrónia és változásvizsgálat (az összetett mondatokban). Magyar Nyelvör 125: 354-70.

Haader Lea 2003. Mondattörténet. In: Kiss Jenő - Pusztai Ferenc (szerk.): Magyar nyelvtörténet. Osiris, Budapest, 677-90, 770-5.

Haader Lea 2004. Változások a történeti szintaxisban - pragmatikai háttérrel. Magyar Nyelvör 128: 464-9.

Haader Lea 2018. Az összetett mondatok. In: Kiss Jenő - Pusztai Ferenc (szerk.): A magyar nyelvtörténet kézikönyve. Tinta Könyvkiadó, Budapest, 209-25.

Hadrovics László 1969. A funkcionális magyar mondattan alapjai. Akadémiai Kiadó, Budapest.

Juhász Dezső 1991. A kötőszók. In: Benkő Loránd (föszerk.): A magyar nyelv történeti nyelvtana I. Akadémiai Kiadó, Budapest, 475-500.

Juhász Dezső 1992. A kötőszók. In: Benkő Loránd (föszerk.): A magyar nyelv történeti nyelvtana II/1. Akadémiai Kiadó, Budapest, 772-814.

Juhász Dezső 1999. Az ómagyar nyelvi normáról és Sylvester nyelvtanáról néhány kötőszó kapcsán. Magyar Nyelv 95: 453-6.

Juhász Dezső 2002. Magyar nyelvjárástörténet és történeti szociolingvisztika: tudományszemléleti kérdések. In: Hoffmann István - Juhász Dezső - Péntek János (szerk.): Hungarológia és dimenzionális nyelvszemlélet. Debrecen-Jyväskylä, 165-73.

Juhász Dezső 2018. A nyelvjárások történetéből. In: Kiss Jenő - Pusztai Ferenc (szerk.): A magyar nyelvtörténet kézikönyve. Tinta Könyvkiadó, Budapest, 361-78.

Papp Zsuzsanna 1995. A mellérendelö mondatok. In: Benkő Loránd (föszerk.): A magyar nyelv történeti nyelvtana II/2. Akadémiai Kiadó, Budapest, 719-57.

Roberts, Craige 2004. Context in Dynamic interpreatation. In: Horn, Laurence - Ward, Gregory (eds.): The Handbook of Pragmatics. Blackwell Publishing Ltd., MaldenOxford-Carlton, 197-220.

Szabó András 2012. A rejtőzködö bibliaforditó Károlyi Gáspár. Kálvin Kiadó, Budapest.

Tagliamonte, Sali A. 2018. Near done; awful stable; really changing: The suffixless adverb in dialects of the UK. Diachronica 35: 107-43. https://doi.org/10.1075/dia.16027.tag

Varga Mónika 2017. „Nem szólhatván, az Úristent segítségül hívta” - A fonák okság kifejezéséröl középmagyar szövegekben. Magyar Nyelv 113: 59-74. https://doi.org/10.18349/ MagyarNyelv.2017.1.59

\section{Varga Mónika}

tudományos segédmunkatárs

Nyelvtudományi Intézet

https://orcid.org/0000-0002-5389-2167 


\section{SUMMARY}

Varga, Mónika

\section{On adversative coordination based on translations of the Bible from the 16-17th centuries: variation and change}

This paper studies the variation of diverse types and interpretations of adversative coordination in the Middle Hungarian period, based on the data of parallel passages of several different Hungarian translations of the Bible from the 16-17th centuries. One of the main topics is the diffusion of corrective de 'but' (the older variant) and hanem 'but rather' (the innovative variant), arguing that the scope of the conjunction can be considered to be a constructional constraint of the change (according to data from Jordánszky Codex). Another main topic explored is the variation of de 'but' and the adversative use of és 'and', shedding light on the tendencies of the usage of the era. The analysis shows that counter-expectational use of contrast is expressed in a direct way (with de 'but') in the passages of Jordánszky Codex and the Bible of Vizsoly, turning the readers' attention immediately to the contrast, while (in the translations of János Sylvester and György Káldi) there was also a tendency of combining these clauses with és 'and', showing the ambiguous nature of the relations, thus involving a proffered interpretation.

Keywords: adversative coordination, variation, diffusion, change, translations of the Bible, Middle Hungarian Period.

\section{Pragmatika és pszicholingvisztika összekapcsolódásának változatai ${ }^{1}$}

A pszichopragmatika az utóbbi fél évszázad során kétszer született meg. Ha a pragmatika tág, Morris- (1975; róla 1. Nagy 2005) féle felfogásából indulunk ki, amely szerint a pragmatika a jelek és a használók viszonya, akkor elvont szinten minden pszicholingvisztika valójában pragmatika. A ,pszichopragmatika” azonban szükebben értelmezte ezt a viszonyt. A nyelv használati kereteinek értelmezését a pszichológiai kutatás adatigényeihez próbálta kapcsolni. Kezdetben individualisztikus keretet használt. Elsősorban arra volt kíváncsi, hogy a használók mint egyének reprezentációiban hogyan jelennek meg a jelek szintaxisán és szemantikáján túlmutató mozzanatok, hogyan egészíti ki a kontextus leképezése és a külvilág ismerete a feldolgozást. Az újabb szakaszban ez az illesztés is társas fordulatot vett: az elsődleges kérdéssé az vált, hogy hogyan képezik le a beszélők a partnerek tudásait, és ez hogyan befolyásolja nyelvi tevékenységüket (Reboul-Moeschler 2006). Hasonló változás nemcsak a pszichopragmatikában, hanem a nyelvészeti pragmatikában is végbement. Tátrai Szilárd (2011, 2013) magyarul is jól összefoglalja ezt a váltást.

1 Ez a dolgozat 3 előadáson alapul. Az elsőt a Pannon Egyetem Pszicholingvisztikai Nyári Egyetemén, 2018. június 10-én tartottam angolul, a másodikat a Félúton címủ doktoranduszkonferencián az ELTE BTK-n, 2018. október 11-én magyarul, a harmadik változatot pedig a X. DUCOG konferencián bemutatott poszterem képviseli, 2018. május 15-éröl. Köszönöm Forgács Bálint (ELTE) és Schnell Zsuzsa (PTE) kommentárjait a kézirathoz. 